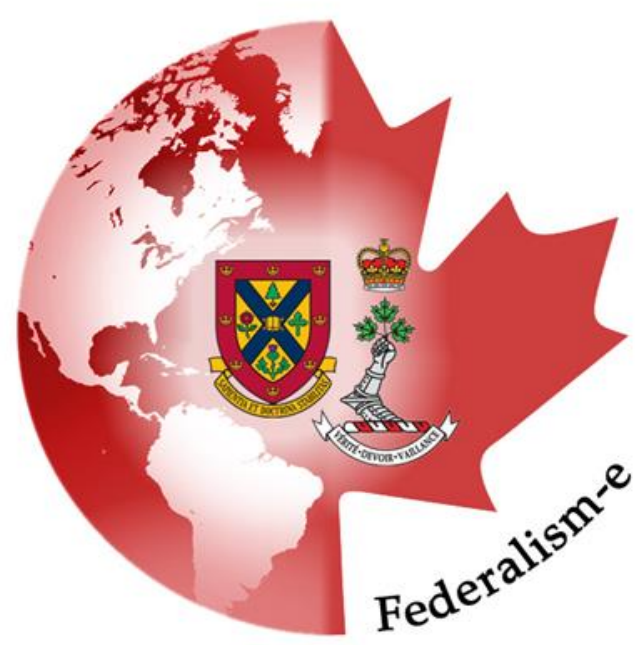

A Gay Federation:

\title{
The Effects of Federalism on the Lesbian and Gay Movement in Canada
}

\section{MORAG KEEGAN-HENRY \\ University of Victoria}

Alan Cairns argues that "federalism is not enough" to deal with non-territorial minorities. ${ }^{1}$ This certainly seems to have been the case with the Canadian LGBT (lesbian, gay, bisexual, and transgender) $^{2}$ movement. In some ways,

${ }^{1}$ Alan Cairns, "Constitutional Government and the Two Faces of Ethnicity: Federalism is Not Enough" in Rethinking Federalism: Citizens, Markets, and Governments in a Changing World. ed. Karen Knop (Vancouver: UBC Press, 1995) p. 27 Note that Cairns is specifically discussing ethnicity, but the lessons can be applied to the lesbian and gay movement as well.

${ }^{2}$ This essay will focus on lesbian and gay rights. An entire book could be written about the exclusion of bisexual and transgender issues from the 'LGBT' movement, and particularly from questions of same-sex marriage and discrimination. The question of whether bisexuals are covered by lesbian and gay rights is a complicated and politically charged one, and transgendered individuals are an entire separate political federalism (the specific system of sovereigntysharing wherein both levels of government are co-equal and each is sovereign in areas under its jurisdiction) has directly inhibited attempts to stop discrimination, provide benefits to common-law same-sex partners, and legalize same-sex marriage. First, prior to the introduction of the Charter of Rights and Freedoms in 1982, human rights cases were usually decided on the basis of jurisdiction, thus severely limiting the ability of activists to challenge discriminatory laws. Second, activists who wish to limit the allocation of rights to gays and lesbians have used arguments regarding

question. Currently, it is likely that transgender rights are covered by Human Rights Acts in all provinces under 'sex,' but only the Northwest Territories specifically addresses this question. A bill to incorporate Transgender into the Charter has been debated by the federal Parliament many times, but has yet to pass. As such, while these issues are both fascinating and pertinent, this essay will overall disregard the questions of bisexual and transgender rights. 
provincial rights to frame the debate as a question of constitutionality rather than of strictly human rights. Third, issues under provincial jurisdiction are susceptible to the use, under Section 33 of the Charter, of the Notwithstanding Clause by provincial governments, which is a concern when provincial elites are opposed to lesbian and gay rights. Other authors argue that the specific arrangement of Canadian federalism has actually been beneficial for minorities, including the lesbian and gay community, especially when compared to that of the United States. ${ }^{3}$ First, federalism provides "laboratories" 4 where provinces can serve as sources of innovation for new laws and activities that will later be replicated federally. Second, the centralization of Canadian federalism has sped up the adoption of progressive legislation in areas such as the decriminalization of sodomy. Third, the existence of Quebec and the challenges to national unity posed by federalism were partially responsible for Prime Minister Pierre Trudeau's construction of rights discourse and the Charter. As such, the existence of Quebec and the tensions created by federal-provincial relations are responsible for the ability of the lesbian and gay community to use Charter provisions in order to gain equality. We will see, however, that although there is some truth to these claims, the cumulative effect of the federal structure of Canadian governance has been to impede the lesbian and gay movement.

To begin with, prior to the Charter, human rights cases were usually decided on the basis of jurisdiction, thus severely limiting the ability of activists to challenge discriminatory

\footnotetext{
${ }^{3}$ Miriam Smith, Political Institutions and Lesbian and Gay Rights in the United States and Canada. (New York:Routledge, 2008.)

${ }^{4}$ Howard, A. E. Dick. "Does Federalism Secure or Undermine Rights?" in Federalism and Rights, eds. Ellis Katz and George Alan Tarr, (Maryland: Rowman \& Littlefield Publishers, Inc., 1996) p. 17
}

laws. ${ }^{5}$ Unlike in the United States, where the Bill of Rights has been a part of the constitution since the $1800 s,{ }^{6}$ Canadian courts had no way to challenge government legislation except as a question of the correct division of powers. The existence of provincial or federal Bills of Rights was of no help in this situation, as said bills were only applicable to areas solely under that level of government's jurisdiction. These existing acts, such as Prime Minister Diefenbaker's Bill of Rights, ${ }^{7}$ were not constitutionally entrenched and thus could be overturned by any new government legislation. This problem can be seen in the many court cases on discrimination which took place throughout the 1970s, where the general attitude toward gay and lesbian rights was, as reflected in University of Saskatchewan v. Saskatchewan Human Rights Commission, that "decriminalization does not mean protection of human rights." ${ }^{8}$ It took a new constitutional device, the Charter of Rights and Freedoms, to force governments to more seriously address human rights issues, including those of the lesbian and gay community. Not only did this new Charter create a constitutional imperative to protect marginalized groups, it was also necessary to shift public discourse from a focus on regionalized divisions, and to help Canada move towards developing a new national identity that focused instead upon the rights of the individual. ${ }^{9}$ Once the Charter was in place, a series of court decisions, including Egan v. Canada 1995, "read" sexual orientation into S. $15 .^{10}$ In 1996, the federal government officially amended the federal Human Rights Act to include sexual orientation and, by 2004, all

\footnotetext{
${ }^{5}$ Smith, Political Institutions p. 42

${ }^{6}$ Smith, Political Institutions p. 21

${ }^{7}$ Miriam Smith. Lesbian and Gay Rights in Canada: Social Movements and Equality-Seeking, 19711995. (Toronto: University of Toronto Press, 1999) p. 42

${ }^{8}$ Paul Mazur, "Gay and Lesbian rights in Canada: $A$ Comparative Study" International Journal of Public Administration 25 (2002) p. 52

${ }^{9}$ Smith, Political Institutions p. 53

${ }^{10}$ Smith, Political Institutions p. 96
} 
jurisdictions in Canada had done the same. ${ }^{11}$ As such, the changes initiated by the Charter suggest that the Canadian obsession with federalism and the rights of provincial minorities seriously limited the ability of Canadian lesbian and gay activists to challenge their exclusion from public discourse and the courts.

In a related way, because of the division of powers and the decentralized authority of the provinces, the use of the Charter in areas of provincial jurisdiction has occasioned debate around the legitimacy of national rights and values overriding elected provincial legislatures and their explicit intentions. ${ }^{12}$ Furthermore, some authors argue that the privileging of courts under the Charter hides a federal bias. ${ }^{13}$ The Supreme Court is appointed by the Prime Minister, and thus, argue these analysts, tends to demonstrate favouritism towards federal initiatives and values rather than provincial interests. ${ }^{14}$ These two arguments are useful tools for activists who wish to oppose lesbian and gay rights without becoming implicated in human rights discourse, allowing them to frame the question, instead, as one of constitutionality and "community rights". The primary example of this in the lesbian and gay movement was the Vriend v. Alberta (1998) case, where an openly gay man was fired from his job at a Catholic school. ${ }^{15}$ The original case, in the Alberta Court of Appeal, focused not on human rights grounds, but rather on the constitutionality of a federally created charter and un-elected court overriding the

\footnotetext{
${ }^{11}$ Smith, Political Institutions p. 2

${ }^{12}$ Anthony Peacock, "Judicial Rationalism and the Therapeutic Constitution: The Supreme Court's Reconstruction of Equality and Democratic Process under the Charter of Rights and Freedoms" in The Myth of the Sacred: the Charter, the Courts and the Politics of the Constitution in Canada, eds. Patrick James, Donald Abelson and Michael Lusztig, (McGill-Queen's University Press 2002) p. 18

${ }^{13}$ Smith, Lesbian and Gay Rights p. 75

${ }^{14}$ Smith, Lesbian and Gay Rights p. 75

${ }^{15}$ Smith, Political Institutions p. 99-100
}

elected provincial legislature. According to one author, the exclusion of sexual orientation from the Alberta Human Rights Act was a conscious choice by the legislature, with the decision reiterated in no less than 6 succeeding debates. ${ }^{16}$ The Charter, on the other hand, was a 'federal document', which ought not to overrule provincial decisions in areas of provincial jurisdiction, as this "undermined the constitutional division of powers". ${ }^{17}$ Thus, in the original decision, the court ruled that the Charter violated provincial rights, and Vriend lost his case. ${ }^{18}$ When the case went to the Supreme Court, the ruling was overturned as a violation of Section 15 of the Charter. ${ }^{19}$ This example demonstrates how lesbian and gay rights can be obstructed by presenting them as a federal threat to provincial sovereignty.

Finally, the fact that many areas of concern for the movement, such as employment and tenancy security, fall under provincial jurisdiction is a major problem for the lesbian and gay movement, as provinces can use the notwithstanding clause to protect their legislation from Charter challenges. Section 33 of the Charter allows a province to disregard Charter mandates for a period of five years on issues that fall under provincial jurisdiction. ${ }^{20}$ The primary example of this is the Alberta Marriage Act. In 2000, Alberta made a clear statement in the Marriage Act that it was not going to recognize same-sex marriage and invoked the notwithstanding clause to pre-emptively justify this potential Charter violation. ${ }^{21}$ Of course, marriage is not an area of provincial jurisdiction, and thus had this legislation been tested it likely would have been found unconstitutional. ${ }^{22}$ Nonetheless, this demonstrates how the division

\footnotetext{
${ }^{16}$ William Black, "Vriend, rights and democracy," Constitutional Forum 7 (1996) p. 128

${ }^{17}$ Peacock, "Judicial Rationalism" p. 31

${ }^{18}$ Black, "Vriend, Rights and Democracy" p. 125

${ }^{19}$ Smith, Political Institutions p. 99

${ }^{20}$ Mazur, Gay and Lesbian Rights p. 48

${ }^{21}$ Smith, Political Institutions p. 143

${ }^{22}$ Smith, Political Institutions p. 143
} 
of powers and the notwithstanding clause can be used to deny lesbian and gay rights in areas that really are under provincial jurisdiction. Thus, in the case of Vriend, the Alberta legislature could have used the notwithstanding clause to continue to exclude sexual orientation from the provincial Human Rights Act. ${ }^{23}$

Section 33 also poses a risk to gay and lesbian common-law marriage. In the Canadian welfare state, common-law marriage is central to the distribution of benefits, ${ }^{24}$ and in the 1970's, Canadian courts consistently ruled against gays and lesbians in custody battles, as well as denying claims to pensions and other job-related benefits. $^{25}$ It was not until 1999 that the Supreme Court, in $\mathrm{M}$ v. $\mathrm{H}$, ruled that same-sex couples were governed by the same rules as heterosexual common-law couples under S. 15 of the Charter. $^{26}$ This ruling led to the federal Modernization of Benefits and Obligations Act (2000), which explicitly recognized the rights of same-sex couples in all areas of federal jurisdiction, except marriage. ${ }^{27}$ However, following $\mathrm{M} \mathrm{v}$. $\mathrm{H}$, the legislature of Alberta or any other province could have chosen not to recognize unmarried partners by invoking the notwithstanding clause. Despite the fact that this did not happen, the power of the notwithstanding clause poses a constant threat to the lesbian and gay movement.

Furthermore, the fact that a tool such as the Charter was necessary to override provincial decisions suggests that federalism as a whole had a negative impact on human rights. This is particularly concerning if we accept Howard's argument that smaller units of government, such as the state or province, are much more susceptible to domination by a small group of

\footnotetext{
${ }^{23}$ Smith, Political Institutions p. 100

${ }^{24}$ Smith, Political Institutions p. 113

${ }^{25}$ Mazur, Gay and Lesbian Rights p. 56

${ }^{26}$ Smith, Political Institutions p. 127

${ }^{27}$ Smith, Political Institutions p. 143
}

elites. ${ }^{28}$ This is sometimes the case in the United States, where the need to legalize same-sex marriage on a state-by-state basis has resulted in a slow and difficult process. ${ }^{29}$ Although marriage is not an area of provincial jurisdiction, the provinces do have authority over several other areas of great interest to the lesbian and gay movement. Thus, without the Charter, federalism as a whole can be seen as obstructive to non-territorial minorities, such as the lesbian and gay community.

Some authors argue that Canadian federalism has had a positive effect on the lesbian and gay movement, using the differences between Canadian and American gay and lesbian rights as evidence. ${ }^{30}$ The next section of this essay will assess the validity and nature of this claim.

First, as Howard says, states can act as "laboratories", where ideas are spawned that later lead to federal action. ${ }^{31}$ Further, having a large number of governments "increases the number of access points to the political system, enabling a wider range of issues to come onto the agenda." ${ }^{\prime 2}$ These American statements are equally applicable to the Canadian federation, where much of the innovation around gay and lesbian rights happened in the provinces themselves. In the 1970's, much of the lesbian and gay rights movement was focused on changing public opinion. ${ }^{33}$ Therefore, the focus was on challenging provinces in court in order to

\footnotetext{
${ }^{28}$ Howard, "Does Federalism" p. 22

${ }^{29}$ Christy Glass and Nancy Kubasek. "The Evolution of Same-Sex Marriage in Canada: Lessons the US Can Learn from their Northern Neighbor Regarding SameSex Marriage Rights". Michigan Journal of Gender \& Law 143 (2008-2009) p. 146

${ }^{30}$ See Miriam Smith, Political Institutions, and Glass and Kubasek, "The Evolution of Same-Sex Marriage"

${ }^{31}$ Howard, "Does Federalism" p. 17

${ }^{32}$ Alan Trench. "Federalism." British Journal of Canadian Studies 20 (Sept. 2007) p. 312-313

${ }^{33}$ Smith, Lesbian and Gay Rights p. 41
} 
attempt to force sexual orientation into the provincial Bills of Rights. The first Human Rights Act to prohibit discrimination on the grounds of orientation was the Charte des droits of Quebec, in $1977,{ }^{34}$ and Quebec was an early adopter of laws to protect same-sex parents, ${ }^{35}$ showing how one province can lead the way. Similarly, when it came to the legalization of same-sex marriage, the provinces were at the forefront, with $B C$, Alberta, New Brunswick, Nova Scotia, and Newfoundland all taking steps towards supporting same-sex marriage. ${ }^{36}$ These provincial actions helped to put the question of same-sex marriage on the political agenda in Canada, and the legalization of marriage in eight provinces was a major factor in the federal government's decision to send a reference case to the Supreme Court in 2004. ${ }^{37}$ These two examples show that Canadian federalism has had a positive effect on lesbian and gay rights in creating space for innovation at the provincial level and in providing venues for activists to place issues onto the political agenda.

However, this also seems like an oversimplification of a complicated process. To return to the American example, the states could also serve as venues for innovation, but this process of policy diffusion does not seem to have occurred in that nation. ${ }^{38}$ There is not necessarily a connection between early action on the part of provinces and decision-making by the federal government. In fact, the early adoption of a progressive Human Rights Act in Quebec may have removed a potential lobbying point for the lesbian and gay community in that province that might have helped them to confront federal laws later. ${ }^{39}$ Although the precedents set by provincial

${ }^{34}$ Smith, Political Institutions p. 49

${ }^{35}$ Smith, Lesbian and Gay Rights p. 57

${ }^{36}$ Glass and Kubasek, "The Evolution of Same-Sex Marriage" p. 169

${ }^{37}$ Smith, Political Institutions p. 155

${ }^{38}$ Glass and Kubasek, "The Evolution of Same-Sex Marriage"

${ }^{39}$ Smith, Lesbian and Gay Rights p. 57 courts certainly affected the decision-making of the Supreme Court regarding marriage, it is questionable whether a direct causal claim can be made that general innovation at the provincial level seriously alters the process of incorporating lesbian and gay rights into federal legislation

Second, Smith demonstrates how the centralization of the Canadian federation on specific issues has sped up the institutionalization of lesbian and gay rights in a way that that of the United States, to use a common example, has not. This has happened in two ways: first, the division of power grants certain major areas of jurisdiction to the federal government, including criminal and family law. Second, the Westminster-style Canadian Senate, in its current arrangement, is primarily a partisan rather than regionally representative institution. ${ }^{40}$ When contrasted to America, the Canadian Senate is less inclined to represent smaller, rural provinces in blocking progressive legislation. For these reasons, lesbian and gay activists did not need to win over every region in order to pass favourable federal legislation. One major issue for the lesbian and gay community was the decriminalization of sodomy. ${ }^{41}$ The federal government of Canada decriminalized sodomy in 1969 as part of a sweeping series of reforms to Canada's Criminal Code and in response to some highly publicized cases of arrest, such as that of Everett Klippert. ${ }^{42}$ Although the law is still discriminatory, in that the age of consent is different for sodomy than for other kinds of sexual activity, ${ }^{43}$ this decriminalization made later fights much easier, as the debate was no longer around "criminal behaviour" and being gay was no longer illegal. ${ }^{44}$ Smith compares this Canadian decriminalization of sodomy by the federal government, which

\footnotetext{
${ }^{40}$ Smith, Political Institutions, p. 14

${ }^{41}$ Glass and Kubasek, "The Evolution of Same-sex Marriage" p. 149

${ }^{42}$ Smith, Political Institutions p. 36

${ }^{43}$ Smith, Political Institutions p. 39

${ }^{44}$ Smith, Political Institutions p. 39
} 
happened all at once and with minimal debate, to the American case, where the decriminalization of the act had to be debated in each state legislature because the states have jurisdiction over criminal law. ${ }^{45}$ Similarly, when it came to the official legalization of same-sex marriage, the issue again fell under federal jurisdiction in Canada. Again, unlike in United States, activists only had to lobby one government in order to change nation-wide laws. ${ }^{46}$ Although several provinces had, due to court decisions, legalized same-sex marriage prior to the federal legislation in $2005,{ }^{47}$ once the federal government changed the official law the battle was won nation-wide, unlike in America. As such, the lack of regional representation on these issues had a positive effect on lesbian and gay rights.

However, these examples and the comparison to the United States also demonstrate how the Westminster parliamentary system has allowed a lot of power to be concentrated in the hands of the political executive. ${ }^{48}$ When the political executive has been supportive of lesbian and gay rights, this has been a good thing, permitting swift and unilateral action and restricting the possibility of reversal of legislation. ${ }^{49}$ It also means that individual politicians are less susceptible to lobbying and manipulation, due to the strict party discipline and dominance of the executive. ${ }^{50}$ Thus, while the lack of regional representation in the areas of criminal and family law has been beneficial for the lesbian and gay movement, these benefits may be more due to the Westminster Parliamentary system rather than to the nature of Canadian federalism. Furthermore, this argument suggests that a

\footnotetext{
${ }^{45}$ Smith, Political Institutions p. 55

${ }^{46}$ Glass and Kubasek "The Evolution of Same-Sex Marriage" p. 151

${ }^{47}$ Glass and Kubasek, "The Evolution of Same-Sex Marriage" p. 146

${ }^{48}$ Smith, Political Institutions p. 13

${ }^{49}$ Smith, Political Institutions p. 132

${ }^{50}$ Smith, Political Institutions p. 182
}

unitary state would have been even better for the lesbian and gay movement.

Finally, we have already seen how the Charter has played a central role in forcing change in three out of our four issues. It is apparent that federalism, without the Charter, negatively impacted the lesbian and gay movement, but it can equally be argued that the Charter of Rights and Freedoms originated in the federal system of Canada. Trudeau constructed the rights discourse surrounding the Charter as a direct attempt to respond to the threat of Quebecois nationalism to national unity. ${ }^{51}$ This discourse built until pan-Canadian nationalism became inextricably linked with human rights and other "Canadian" values, thus creating space for gay rights to be inserted into Canadian law. ${ }^{52}$ Thus, the lesbian and gay movement confronted a political discourse of rights, wherein their claims were not, as in the United States, a special interest, $^{53}$ nor, as in pre-Charter Canada, irrelevant to a constitution-obsessed nation, ${ }^{54}$ but rather a part of the Canadian national identity. ${ }^{55}$ Thus, the shift in political discourse and jurisdiction initiated by Charter politics but indirectly originating in the conflict over Quebecois nationalism and thus in the federal

\footnotetext{
${ }^{51}$ Guy LaForest, Trudeau and the end of a Canadian Dream, translated by Paul Brown and Michelle Winroth. (Montreal: McGill-Queen's University Press, 1995) p. 129

52 Jane Jenson. "Citizenship Claims: Routes to Representation in a Federal System" in Rethinking Federalism: Citizens, Markets, and Governments in a Changing World. ed. Karen Knop (Vancouver: UBC Press, 1995) p. 101

${ }^{53}$ Glass and Kubasek, "The Evolution of Same-Sex Marriage" p. 159

${ }^{54}$ Jenson, "Citizenship Claims" p. 110

${ }^{55}$ Richard Simeon and Katherine Swinton. "Introduction: Rethinking Federalism in a Changing World." in Rethinking Federalism: Citizens, Markets, and Governments in a Changing World. ed. Karen Knop (Vancouver: UBC Press, 1995), p. 252
} 
nature of Canadian identity has helped the lesbian and gay movement in Canada. Nonetheless, while this argument is persuasive, it is important to remember that without federalism, Canada might have already had a Charter (or equivalent), and certainly Canada would not have been as obsessed with federal questions to begin with. As such, rights discourse could have originated out of some other issue, and thus this argument does not necessarily conclusively prove that federalism has helped the lesbian and gay movement.

From this examination, it is apparent that Canadian federalism has overall been a stumbling block to the lesbian and gay movement. The focus on jurisdiction rather than on human rights that was characteristic of preCharter political discourse and court decisions meant that gays and lesbians had to wait for the advent of the Charter of Rights and Freedoms in order to have a serious chance at gaining equality. This focus on jurisdiction continues, even under the Charter, as opponents continue to frame the debate in terms of provincial rights. Furthermore, if provinces so decide, they can use the notwithstanding clause to block future action on lesbian and gay issues. Although provinces can serve as areas of innovation in which to get new issues onto the political agenda, it is unclear that this was necessarily any motivation for any of the federal actions, except perhaps the legalization of same-sex marriage. As well, although the centralized nature of Canadian federalism may have been an improvement over the decentralized American one, this argument also suggests that federalism in general is detrimental to lesbian and gay rights, and a unitary state may be preferential. Finally, although it is true that the Charter emerged out of Trudeau's attempt to protect national unity from regional conflicts exacerbated by federalism, this does not mean that a Charter could not have emerged for some other reason had Canada been a unitary state. Therefore, it seems as though Alan Cairns had it right when he argued that federalism, while ideal for dealing with territorially concentrated minorities, actually aggravates the issue around nonterritorial minorities such as the lesbian and gay community. 


\section{Bibliography}

Black, William. "Vriend, rights and democracy," Constitutional Forum 7 (1996) p. 126-132

Cairns, Alan. "Constitutional Government and the Two Faces of Ethnicity: Federalism is Not Enough" in Rethinking Federalism: Citizens, Markets, and Governments in a Changing World. ed. Karen Knop (Vancouver: UBC Press, 1995)

Elazar, Daniel. "Federalism, Diversity, and Rights" in Federalism and Rights, eds. Ellis Katz and George Alan Tarr, (Maryland: Rowman \& Littlefield Publishers, Inc., 1996)

Glass, Christy, and Nancy Kubasek. "The Evolution of Same-Sex Marriage in Canada: Lessons the US Can Learn from their Northern Neighbor Regarding Same-Sex Marriage Rights". Michigan Journal of Gender \& Law 143 (2008-2009) p. 143-197

Howard, A. E. Dick. "Does Federalism Secure or Undermine Rights?" in Federalism and Rights, eds. Ellis Katz and George Alan Tarr, (Maryland: Rowman \& Littlefield Publishers, Inc., 1996)

Jenson, Jane. "Citizenship Claims: Routes to Representation in a Federal System" in Rethinking Federalism: Citizens, Markets, and Governments in a Changing World. ed. Karen Knop (Vancouver: UBC Press, 1995)

LaForest, Guy. Trudeau and the end of a Canadian Dream, translated by Paul Brown and Michelle Winroth. (Montreal: McGill-Queen's University Press, 1995)

Lajoie, Andrée. "Le fédéralisme au Canada: provinces et minorités, même combat." in Le Fédéralisme Canadien Contemporain - Fondements, Traditions, Institutions, ed. Alain-G. Gagnon (Montréal: Les Presses de l'Université de Montréal, 2006)

Mazur, Paul. "Gay and Lesbian rights in Canada: A Comparative Study" International Journal of Public Administration 25 (2002) p. 45-62

Peacock, Anthony. "Judicial Rationalism and the Therapeutic Constitution: The Supreme Court's Reconstruction of Equality and Democratic Process under the Charter of Rights and Freedoms" in The Myth of the Sacred: the Charter, the Courts and the Politics of the Constitution in Canada, eds. Patrick James, Donald Abelson and Michael Lusztig, (McGill-Queen's University Press 2002)

Simeon, Richard and Katherine Swinton. "Introduction: Rethinking Federalism in a Changing World." in Rethinking Federalism: Citizens, Markets, and Governments in a Changing World. ed. Karen Knop (Vancouver: UBC Press, 1995)

Smith, Miriam. Lesbian and Gay Rights in Canada: Social Movements and Equality-Seeking, 1971-1995. (Toronto: University of Toronto Press, 1999)

Smith, Miriam. Political Institutions and Lesbian and Gay Rights in the United States and Canada. (New York:Routledge, 2008.) 
Trench, Alan. "Federalism." British Journal of Canadian Studies 20 (Sept. 2007) p. 312-313 